\title{
THE LIBERATION OF CELL-BOUND VACCINIA VIRUS BY ULTRASONIC VIBRATION
}

\author{
BY I. A. MACPHERSON \\ Microbiological Research Establishment, Ministry of Supply, Porton, Wiltshire
}

\section{INTRODUCTION}

A true estimate of the virus content of infected tissues will only be obtained if all the complete virus particles are released from the cells and suspended without inactivation as individual infectious units. This is particularly important in the early stages of a growth cycle when an eclipse phase may be present.

When the infected cells are present in the form of tissues or pieces of tissue only crude methods of cell disintegration are available such as grinding with abrasives or homogenizing in a blendor. Standard blendors produce very little cell breakdown, and Anderson (1954) has shown that some methods of grinding cause considerable reductions in the infectivity of vaccinia and other virus suspensions.

With tissue-culture material more elegant techniques are applicable for the release of virus, and the increasing importance of tissue culture for the intimate study of virus multiplication and for the large-scale production of virus suspensions make a detailed investigation of such methods desirable.

In this communication comparisons of several methods of liberating vaccinia virus from suspensions of infected HeLa cells are presented and the high efficiency of ultrasonic vibration for this purpose is clearly demonstrated. Virus suspensions obtained by this method are probably close to the ideal yield of infectious units from these cells.

\section{MATERIALS AND METHODS}

Titration of virus in eggs. Virus was titrated on the chorio-allantois of developing hen's eggs as described by Westwood, Phipps \& Boulter (1957) and results expressed in pock-forming units (P.F.U.) per ml.

Vaccinia virus. A semi-purified elementary-body suspension was prepared from rabbit-skin pulp by differential centrifugation, diluted to a concentration of $10^{8}$ P.F.U. $/ \mathrm{ml}$. in skimmed milk, and stored at $-60^{\circ} \mathrm{C}$.

HeLa cell suspensions. HeLa cells were grown on glass in $15 \%$ calf-serum medium plus protein digests (Westwood, Macpherson \& Titmuss, 1957) until they were nearly confluent. The cells were detached from the glass by replacing the medium with an equal volume of $0.05 \%$ di-sodium ethylene diamine tetra-acetic acid (EDTA-B.D.H. Ltd.) solution in isotonic phosphate buffered saline (PBS) at pH $7 \cdot 2$. The culture was incubated at $37^{\circ} \mathrm{C}$. for $5 \mathrm{~min}$. and then gently shaken to dislodge the cells.

The cells were sedimented by low-speed centrifugation, washed three times in $0.5 \%$ calf serum in PBS, and suspended in the same fluid to a concentration of $10^{6}$ cells per $\mathrm{ml}$. 
Vaccinia infected HeLa cell suspensions. Nearly confluent HeLa cultures were infected with a dose of vaccinia virus adjusted to give a virus/cell ratio of about 1/500. Two days later small holes surrounded by vacuolated syncytia appeared in the cell sheet, these plaques being the first definite sign of viral cytopathogenicity. The ratio of pock-forming units in the inoculum to plaques produced in the HeLa cultures was usually $7: 1$. At this stage the cells were harvested and washed in the way described for normal cells. This treatment did not disrupt the virus-induced syncytia.

\section{Methods used for disintegration of cells}

Ultrasonic vibration. A Mullard $500 \mathrm{~W}$., 2 Mcyc./sec. transducer of the quartzcrystal type was used. The applied voltage was kept constant at $1.8 \mathrm{kV}$. The transducer was immersed in a water bath at $2^{\circ} \mathrm{C}$. and the chamber containing the cell suspension was supported $1 \mathrm{~cm}$. above it in the water. A pump induced a rapid flow of water between the upper surface of the transducer and the lower wall of the chamber. The chamber was constructed from Perspex $8 \times 5 \times 0.7 \mathrm{~cm}$. A hole $3 \mathrm{~cm}$. in diameter was drilled through it and a central chamber completed by sealing cover-glasses $(38 \times 38 \times 0.2 \mathrm{~mm}$.) on either side of the hole with silicone grease. 'Araldite' resin was then applied to the edges of the cover-glass to complete the seal. Drill holes through the edge of the Perspex into the central chamber provided access for filling and emptying the chamber with Pasteur pipettes, and these were sealed with a strip of water-proof adhesive tape. A $2 \mathrm{ml}$. volume of cell suspension was treated at one time. When the chamber was in position the instrument was tuned until the largest possible fountain appeared above the upper cover-glass. This state is referred to below as maximum turbulence.

Although the Perspex chamber was used in all the experiments described in this communication, a simpler container has been found to be equally effective. A $1 \mathrm{oz}$. wide-mouthed, screw-capped bottle had a circular hole ( $\frac{5}{8}$ in. diameter) punched through the metal cap and rubber liner and a circular piece of aluminium foil $(0.025 \mathrm{~mm}$. thick) was placed between the punched liner and screw cap. The bottle, containing up to $15 \mathrm{ml}$. of suspension, was inverted and clamped over the transducer for treatment.

Freezing and thawing. $1 \mathrm{ml}$. of cell suspension was frozen rapidly by immersing the tube containing the suspension in a solid $\mathrm{CO}_{2} /$ ethanol bath for $10 \mathrm{~min}$. and then thawed in a $37^{\circ} \mathrm{C}$. water bath. Each sample was given three cycles of treatment.

Grinding in a TenBroeck tissue disintegrator. (TenBroeck, 1931.) $2 \mathrm{ml}$. of suspension was ground for 10 or $15 \mathrm{~min}$. in a $5 \mathrm{ml}$. grinder immersed in an ice-bath.

Grinding with sand. $5 \mathrm{ml}$. of suspension was ground with $4 \mathrm{~g}$., of acid-cleaned sand for $5 \mathrm{~min}$. with a porcelain pestle and mortar cooled to $4^{\circ} \mathrm{C}$.

Shaking with glass beads. $6 \mathrm{ml}$. of suspension was added to $5 \mathrm{~g}$. of Ballotini beads, size ' 9 ' or ' 14 ', and shaken in a standard Mickle disintegrator (Mickle, 1948) at $4^{\circ} \mathrm{C}$. The mean diameters of size 9 and size 14 beads are 0.35 and $0.11 \mathrm{~mm}$, respectively. 


\section{RESULTS}

The use of EDTA solution for dislodging vaccinia infected cells from the glass of the culture vessels will be permissible only if it has no effect on the infectivity of the virus.

The effect of di-sodium ethylene diamine tetra-acetic acid (EDTA) on vaccinia virus

Two vaccinia virus suspensions were prepared in PBS. Two samples of each suspension were diluted with equal volumes of PBS and $0.1 \%$ EDTA in PBS, respectively. Following incubation at $37^{\circ} \mathrm{C}$. for 15 and $30 \mathrm{~min}$., respectively, the virus suspensions were titrated in eggs. Since there was no fall in infectivity in either of the EDTA treated suspensions (Table 1) it was considered justifiable to use this substance for the preparation of suspensions of infected cells.

Table 1. Effect of EDTA on vaccinia virus

$\left.\begin{array}{ccccc}\text { Expt. } & \text { Suspending } & \begin{array}{c}\text { Duration of } \\ \text { incubation at }\end{array} & \begin{array}{c}\text { Probability } \\ \text { of common } \\ \text { mean }\end{array} \\ 1 & \text { fluid } & 37^{\circ} \text { C. (min.) } & \text { P.F.U./ml. } & (\%) \\ 2 & \text { PBS } & 15 & 410 & \\ 2 & \text { EDTA } & 15 & 450\end{array}\right)$

Methods of cell disintegration

Cell disintegration techniques used to release virus from infected cells should (i) reduce the cells to very small fragments, and (ii) have no effect on the infectivity of the virus.

\section{Effect of HeLa cells}

Ultrasonics. Suspensions of HeLa cells were subjected to maximum ultrasonic turbulence for varying periods and then stained by adding an equal volume of $0.5 \%$ trypan blue in PBS. According to Girardi, McMichael \& Henle (1956) dead cells and cell fragments accept this stain and viable cells remain unstained. The cell suspensions in stain were counted in a haemocytometer and the proportion of cells affected by each treatment was estimated.

After 2 min. treatment all the cells stained with trypan blue, and more than $95 \%$ had been fragmented into pieces smaller than half the original cell diameter. After $5 \mathrm{~min}$. treatment the suspension consisted of cell fragments each smaller than one-tenth of the original cell diameter. When the instrument was tuned to operate below maximum turbulence the time required to break up the cells was increased considerably, and very little fragmentation occurred even after $30 \mathrm{~min}$. treatment.

Other methods. Shaking with glass beads in a Mickle disintegrator reduced the cells to very small fragments in less than $1 \mathrm{~min}$.

Grinding in a TenBroeck disintegrator gave variable results probably due to the 
ground-glass surfaces of the grinders having different amounts of wear. Although all cells were stained after $15 \mathrm{~min}$. grinding, more than $20 \%$ remained entire.

Grinding with sand usually disintegrated all the cells, but did not reduce them to such small pieces as ultrasonic vibration or shaking with glass beads.

Three cycles of freezing and thawing did not produce much disintegration and up to $20 \%$ of the cells remained unstained after treatment.

Ultrasonic vibration and shaking with glass beads fulfil the first requirement adequately, and may therefore be expected to give higher yields of virus than other methods if they do not cause simultaneous virus inactivation.

\section{Effect on virus}

Ultrasonics. Several workers have reported that ultrasonics do not inactivate vaccinia elementary bodies (Paic, Haber, Voet \& Eliasz, 1935, and Hopwood, Salaman \& McFarlane, 1939). Grabar (1953) suggested that negative results in attempts to inactivate vaccinia virus might be explained by the use of ultrasonic waves of insufficient energy, by too dense suspensions or by the protective action of tissue debris. This last belief is supported by the evidence of Yaoi \& Nakahara (1934) who showed that crude suspensions of vaccinia virus were not inactivated by ultrasonics, but chemically purified suspensions were destroyed by very short exposures. A similar effect was demonstrated by Rivers, Smadel \& Chambers (1937). They suggest that the presence of protein protects the virus from inactivation by $\mathrm{H}_{2} \mathrm{O}_{2}$ which is known to be produced by the action of ultrasonic vibration on water. During the disruption of infected tissues, cellular debris will always be present and should provide an adequate amount of protective protein.

Five minutes treatment at maximum turbulence suffices to produce efficient fragmentation of HeLa cells, but the effect of longer treatments on suspensions of vaccinia virus elementary bodies was investigated. Dilute suspensions of virus were prepared in $0.5 \%$ calf serum in PBS and $2 \mathrm{ml}$. samples were treated as described in Table 2.

Table 2. Effect of ultrasonic vibrations on suspensions of vaccinia virus

\begin{tabular}{|c|c|c|c|c|c|}
\hline Expt. & Treatment & $\begin{array}{c}\text { Mean } \\
\text { temperature } \\
\text { of water } \\
\text { bath } \\
\left({ }^{\circ} \mathrm{C} .\right)\end{array}$ & $\begin{array}{l}\text { Duration } \\
\text { of } \\
\text { treatment } \\
\text { (min.) }\end{array}$ & P.F.U./ml. & $\begin{array}{c}\text { Probability } \\
\text { of common } \\
\text { mean } \\
(\%)\end{array}$ \\
\hline 1 & $\begin{array}{l}\text { None } \\
\text { Ultrasonics }\end{array}$ & $\begin{array}{l}2 \\
2\end{array}$ & $\overline{10}$ & $\left.\begin{array}{l}603 \\
572\end{array}\right\}$ & c. 70 \\
\hline 2 & $\begin{array}{l}\text { None } \\
\text { Ultrasonics }\end{array}$ & $\begin{array}{l}2 \\
2\end{array}$ & $\overline{15}$ & $\left.\begin{array}{l}350 \\
380\end{array}\right\}$ & c. 60 \\
\hline 3 & $\begin{array}{l}\text { None } \\
\text { Ultrasonics }\end{array}$ & $\begin{array}{l}2 \\
2\end{array}$ & $\overline{20}$ & $\left.\begin{array}{l}141 \\
153\end{array}\right\}$ & c. 50 \\
\hline 4 & $\begin{array}{l}\text { None } \\
\text { Ultrasonies }\end{array}$ & $\begin{array}{l}16 \\
16\end{array}$ & $\frac{-}{10}$ & $\left.\begin{array}{l}497 \\
513\end{array}\right\}$ & c. 80 \\
\hline 5 & $\begin{array}{l}\text { None } \\
\text { Ultrasonics }\end{array}$ & $\begin{array}{l}21 \\
21\end{array}$ & $\overline{15}$ & $\left.\begin{array}{l}384 \\
357\end{array}\right\}$ & c. 60 \\
\hline
\end{tabular}


The results in Table 2 clearly show that ultrasonic doses several times in excess of those required for complete HeLa cell disintegration have no effect on the infectivity of vaccinia virus suspensions even when the treatment is carried out at room temperature and in the absence of a cooling jet of water.

Shaking with glass beads. Six ml. volumes of virus suspension were shaken with 5 g. amounts of beads. The results (Table 3) were variable but it was clear that shaking with the smaller beads (size 14) caused a loss of infectivity and shaking with the larger beads (size 9) sometimes did so.

Table 3. Effect of shaking vaccinia virus suspensions with glass beads

\begin{tabular}{|c|c|c|c|c|}
\hline Expt. & Treatment & $\begin{array}{l}\text { Duration } \\
\text { of } \\
\text { treatment } \\
\text { (min.) }\end{array}$ & P.F.U. $/ \mathrm{ml}$. & $\begin{array}{c}\text { Probability } \\
\text { of } \\
\text { common } \\
\text { mean } \\
(\%)\end{array}$ \\
\hline 1 & $\begin{array}{l}\text { None } \\
\text { Shaken with size } 9 \text { beads }\end{array}$ & $\overline{5}$ & $\left.\begin{array}{l}603 \\
603\end{array}\right\}$ & c. 100 \\
\hline 2 & $\begin{array}{l}\text { None } \\
\text { Shaken with size } 9 \text { beads }\end{array}$ & $\overline{5}$ & $\begin{array}{l}375 \\
300\end{array}$ & c. 20 \\
\hline 3 & $\begin{array}{l}\text { None } \\
\text { Shaken with size } 9 \text { beads }\end{array}$ & $\overline{5}$ & $\left.\begin{array}{r}497 \\
91\end{array}\right\}$ & $0 \cdot 1$ \\
\hline 4 & None & - & 398 & $\begin{array}{l}\text { Compared with } \\
\text { others }\end{array}$ \\
\hline & $\begin{array}{l}\text { Shaken with size } 9 \text { beads } \\
\text { Shaken with size } 14 \text { beads }\end{array}$ & $\begin{array}{l}5 \\
5\end{array}$ & $\begin{array}{r}225 \\
52\end{array}$ & $\begin{array}{l}1 \\
0 \cdot 1\end{array}$ \\
\hline
\end{tabular}

Table 4. The loss of infectivity in vaccinia virus suspensions following contact with small glass beads

\begin{abstract}
Treatment of virus suspensions ( $5 \mathrm{hr}$.)
\end{abstract}

Stationary without beads

Rolled without beads

Stationary with size 9 beads

Rolled with size 9 beads

Stationary with size 14 beads

Rolled with size 14 beads

$\begin{array}{cc}\text { Expt. } 1 \text { at } 4^{\circ} \mathrm{C} . \\ \begin{array}{c}\text { P.F.U./ } \\ 0.1 \mathrm{ml} .\end{array} & \begin{array}{c}\text { \% loss } \\ \text { of virus }\end{array} \\ 4840 & \text { Control } \\ 4070 & 15 \\ 1860 & 70 \\ 180 & 97 \\ 2130 & 53 \\ 7 & 99.8\end{array}$

While it was possible that this loss of infectivity might be due to mechanical disruption of the virus, adsorption onto the surface of the beads was considered the more likely cause, the greater loss of infectivity in the presence of the smaller beads being due to their greater surface area. This was further investigated. Six ml. volumes of virus suspension in $0.5 \%$ calf serum in PBS were placed in $15 \mathrm{ml}$. neutral glass bottles and treated for $5 \mathrm{hr}$. according to the scheme described in Table 4. Horizontal rolling of the bottles with beads at 4 r.p.m. produced only a very gentle cascading of the beads into the fluid.

Since simple contact of the virus suspension with stationary glass beads produced a significant loss of virus, mechanical disruption could be excluded and the 
losses of infectivity shown in Table 4 can best be explained as being due to adsorption. In the light of these results it seems likely that the inefficiency of homogenizing methods using finely divided abrasives such as sand and glass powder may similarly be attributable to loss of virus by adsorption.

\section{Ultrasonic vibration compared with other methods of homogenization as a means} of liberating vaccinia virus from infected HeLa cells

Suspensions of infected HeLa cells were disintegrated by various methods and the concentration of vaccinia virus in the supernatant after centrifuging the treated suspension for $10 \mathrm{~min}$. at 1000 r.p.m. was measured. From the results in Table 5 it will be seen that ultrasonic vibration and shaking with size 9 glass beads

Table 5. The yields of virus obtained following the homogenization of vaccinia infected HeLa cell suspensions by various methods

\begin{tabular}{|c|c|c|c|c|}
\hline Expt. & 'Treatment & $\begin{array}{l}\text { Duration } \\
\text { of } \\
\text { treatment } \\
\quad \text { (min.) }\end{array}$ & $\begin{array}{l}\text { P.F.U./ } \\
\text { ml. } \times 10^{-3}\end{array}$ & $\begin{array}{l}\text { Probability } \\
\text { of } \\
\text { common } \\
\text { mean } \\
(\%)\end{array}$ \\
\hline 1 & $\begin{array}{l}\text { Ultrasonics } \\
\text { Frozen and thawed } \times 3\end{array}$ & $\underline{2}$ & $\left.\begin{array}{r}261 \\
37\end{array}\right\}$ & $0 \cdot 1$ \\
\hline 2 & $\begin{array}{l}\text { Ultrasonics } \\
\text { TenBroeck ground }\end{array}$ & $\begin{array}{l}15 \\
15\end{array}$ & $\left.\begin{array}{l}6 \\
4\end{array}\right\}$ & l \\
\hline 3 & $\begin{array}{l}\text { Ultrasonics } \\
\text { Ground with sand }\end{array}$ & $\begin{array}{l}5 \\
5\end{array}$ & $\left.\begin{array}{r}150 \\
1\end{array}\right\}$ & $0 \cdot 1$ \\
\hline 4 & $\begin{array}{l}\text { TenBroeck ground } \\
\text { Frozen and thawed } \times 3\end{array}$ & 10 & $\left.\begin{array}{r}136 \\
10\end{array}\right\}$ & 0.1 \\
\hline 5 & $\begin{array}{l}\text { Ultrasonics } \\
\text { Shaken with size } 9 \text { beads } \\
\text { Shaken with size } 9 \text { beads } \\
\text { TenBroeck ground } \\
\text { Frozen and thawed } \times 3\end{array}$ & $\begin{array}{r}10 \\
5 \\
2 \\
10 \\
-\end{array}$ & $\begin{array}{r}29 \\
25 \\
21 \\
10 \\
3\end{array}$ & $\begin{array}{l}\text { Compared with } \\
\text { others } \\
\text { c. } 40 \\
10 \\
0 \cdot 1 \\
0 \cdot 1\end{array}$ \\
\hline 6 & $\begin{array}{l}\text { Shaken with size } 9 \text { beads } \\
\text { Ultrasonics } \\
\text { Ultrasonics }\end{array}$ & $\begin{array}{r}5 \\
10 \\
2\end{array}$ & $\begin{array}{r}101 \\
158 \\
88\end{array}$ & $\begin{array}{c}\text { Compared with } \\
\text { others } \\
0 \cdot 1 \\
2\end{array}$ \\
\hline 7 & $\begin{array}{l}\text { Shaken with size } 9 \text { beads } \\
\text { Shaken with size } 9 \text { beads } \\
\text { Shaken with size } 14 \text { beads } \\
\text { Shaken with size } 14 \text { beads } \\
\text { Ultrasonics }\end{array}$ & $\begin{array}{l}5 \\
1 \\
5 \\
5\end{array}$ & $\begin{array}{r}53 \\
55 \\
8 \\
49\end{array}$ & $\begin{array}{c}\text { Compared with } \\
\text { others } \\
\text { c. } 80 \\
\text { c. } 90 \\
0 \cdot 1 \\
\text { c. } 30\end{array}$ \\
\hline
\end{tabular}

gave consistently higher titres than the other methods investigated. This suggests that the response of virus to shaking with glass beads in the presence of cells differs from that of the purified virus suspension, due possibly to some protective action exerted by the cell debris. However, the inconsistency of the results indicates that the protective action may break down, especially when treatment is prolonged. 


\section{DISCUSSION}

Although it is impossible to say when complete dispersion of cell-bound infectious units has been achieved, it is fair to assume that the ideal has been approximated very closely if two dissimilar methods give closely similar titres, higher than those obtained by other methods. It has been shown in the foregoing results that, within the limits of experimental error, controlled doses of both ultrasonic vibration and shaking with glass beads give the same titre of virus from infected cells. These techniques are probably sufficiently dissimilar in their method of producing cell disintegration to justify the supposition that the amount of virus liberated is close to the maximum possible yield.

Of the two methods ultrasonic disintegration seems preferable. Shaking with glass beads gives inconsistent results and only small volumes of suspension can be handled. On the other hand, ultrasonic vibration gives consistent results and has the added advantage that it could be used for the treatment of large volumes by simple modification of the treatment chamber to permit continuous flow of the cell suspensions. This could be of practical value for the dispersion of virus grown in tissue culture for vaccine production, both with regard to the production of the maximum number of infectious units and also as a preliminary to efficient chemical inactivation such as treatment with formalin. There seems little doubt that the dose of ultrasonics could be adjusted so that the cells would be finely fragmented without causing a loss of viral infectivity.

If low-power ultrasonic disintegrators were designed specifically for the disruption of small amounts of soft tissue, the expense and bulkiness of available equipment, which preclude their use in many laboratories, would be overcome.

\section{SUMMARY}

1. Ultrasonic vibration has been shown to be a highly effective means of releasing vaccinia virus from infected HeLa cells.

2. The titre of vaccinia virus obtained from a suspension of infected HeLa cells following ultrasonic vibration is closely similar to that obtained by rapid shaking of the suspension with glass beads. Since these methods are dissimilar in their disruptive action and the titres obtained are higher than those obtained by other methods, they are probably close to the maximum possible yield of virus from these cells.

3. Ultrasonic vibration and shaking with glass beads give higher yields of vaccinia virus from infected HeLa cells than grinding with sand, grinding in a glass TenBroeck tissue disintegrator and three cycles of freezing and thawing.

I am indebted to Prof. H. B. Maitland whose interest stimulated this work. I also wish to thank Dr J. C. N. Westwood for much helpful criticism and Mr R. F. W. Southey for his technical assistance. 


\section{REFERENCES}

ANDErson, S. G. (1954). The growth curve of vaccinia virus on the chorio-allantois. Aust. J. exp. Biol. med. Sci. 32, 633.

Gmardi, A. J., McMichael, H. \& Henle, W. (1956). The use of Hela cells in suspension for quantitative study of virus propagation. Virology, 2, 532.

Grabar, P. (1953). Biological actions of ultrasonic waves. Advanc. biol. med. Physics, $3,191$.

Hopwood, F. L., Salaman, M. H. \& McFarlane, A. S. (1939). The effect of ultrasonic vibration on vaccinia virus. Nature, Lond., 144, 377.

Mrckle, H. (1948). Tissue disintegrator. J.R. micr. Soc. 68, 10.

Paic, M., Haber, P., Vowt, J. \& Eliasz, A. (1935). Action biologique des ultrasons. C.R. Soc. Biol., Paris, 119, 1063.

Rivers, T. M., Smadel, J. E. \& Chambers, L. A. (1937). Effect of intense sonic vibrations on elementary bodies of vaccinia. $J . \exp . \operatorname{Med} .65,677$.

TenBrowck, C. (1931). A simple grinder for soft tissues. Science, 74, 98.

Westwood, J. C. N., Macpherson, I. A. \& Trtmuss, D. H. J. (1957). Transformation of normal cells in tissue culture. Its significance relative to malignancy and virus vaccine production. Brit. J. exp. Path. 38, 138.

Westwood, J. C. N., Phipps, P. H. \& Boulter, E. A. (1957). The titration of vaccinia virus on the chorioallantoic membrane of the developing chick embryo. J. Hyg., Camb., 55, 123.

Yaor, H. \& Nakahara, W. (1934). Effect of short exposure to supersonic waves on vaccine virus and some bacteria. Jap. J. exp. Med. 12, 131.

(MS. received for publication 23. IV. 57) 